\title{
Development Of Strategic Organizational Learning As A Competitive Advantage In The "Paladars" Of The Sector Sme's Horeca In The Havana, Cuba
}

\author{
Héctor Nuricumbo-Castro, PhD Candidate, Scholarship \\ Student, CONACyT \\ Popular University Autonomous of State Puebla, \\ Interdisciplinary Center for Graduate Studies, Research and Consulting. \\ Autonomous University of Chiapas, \\ Faculty of Accounting and Administration, Campus I. \\ Manuel Moguel-Liévano, PhD SNI-1, CONACyT \\ Autonomous University of Chiapas, \\ Faculty of Accounting and Administration, Campus I. \\ Manuel González-Pérez, PhD SNI-1, CONACyT \\ Popular University Autonomous of State Puebla, \\ Interdisciplinary Center for Graduate Studies, Research and Consulting.
}

\begin{abstract}
The research develops a model of Strategic Organizational Learning (SOL) to acquire and build institutional knowledge as a long-term competitive advantage in family businesses known as paladars. It aims to consolidate and strengthen the SME Horeca sector in Havana, Cuba. The proposed methodology is not experimental and correlational cross-sectional. The Knowledge Transfer equation was implemented to measure the SOL based on the proposed model. Also, it was used to determine the relationship between learning and competition. The equation was validated. The results indicated that most paladars present an SOL Medium/Regular, and independence exists between competition and learning. However, there is great ignorance to foster the organizational culture in the HORECA sector. This study suggests that the arrival of US competition causes these establishments perish.
\end{abstract}

Keywords: Strategic Organizational Learning, Competitive Advantage, Family Businesses, SME HORECA Sector 


\section{Introductions}

The year 2015 has an important connotation for Cuba. The country is going through significant economic, legal and social level changes. Since 2008, the Cuban government has promoted the creation of SMEs due to the decline in foreign investment and a deteriorating economy (Dávalos, 2015).

The country's development relies heavily on the availability and the use of its resources. As a result, they are updating their economic model and national policies. Cuba is the sun and beach destination with historical and cultural attractions, art galleries, boutiques, and souvenir shops (Hoyos, 2014).

The international environment shows great economic and financial crisis. However, this crisis also affected Cuba. The country's economy depends entirely on its external economic relations and imports. However, tourism remains the leading sector of the Cuban economy and is one of the most attractive countries for domestic and foreign investment areas (Dávalos, 2015).

Fragmentation and distribution of highly individualized products and services are the main features of the HORECA sector. Thus, it has the following classification:

- Market manufacture, marketing of equipment, and materials for the Horeca activity.

- $\quad$ Market manufacture and marketing of retail (food and drinks).

- Market services for companies operating in the channel (cleaning, security, and control).

- Market retail (individual units and providing personalized customer service): hotels, restaurants, and caterers companies (Embassy of Spain in Kuwait, Economic and Commercial Office, 2013).

The means of production and businesses in Cuba are state-owned. However, there is a kind of family business called "Paladar." Paladars belong to the retail market and are private restaurants run by independent entrepreneurs. The Cuban government began delivering the first operating licenses in the early 90s of last century. There were many limitations to carry out this type of establishment. They could only serve 12 clients at the same time. Also, they are limited and managed by a family member menu. Most of these restaurants are inside the family home.

The aim of the paper is to develop a new model of strategic organizational learning to acquire and build institutional knowledge as a long-term competitive advantage in family businesses called paladars. Consequently, this model consolidates and strengthens the SME sector HORECA in Havana, Cuba. 
This document incorporates the state of the art of the proposed methodology for analysis. Also, the results and conclusions of the study were supported by the reference.

\section{State of the Art}

The current socioeconomic reality which drives a new way to manage the world of organization and teamwork is essential. Thus, this situation involves bringing together individuals with a certain profile. Also, it takes into account some aspects that give complexity to the issue. A necessary but not sufficient condition is to have people and equipment ready for the organization to generate and use knowledge better than others (StableRodriguez, 2016).

Organizational Learning (OL) can be considered to be multidisciplinary. The OL incorporates the knowledge of various theoretical fields such as psychology, sociology, economics, anthropology, politics, history, and management with strong growth from 1990 (Antonello \& Godoy, 2011).

In this decade, the trend considers the creation of knowledge as one of the processes of knowledge management (Alavi \& Denford, 2011). The level of organizational learning occurs at three levels: individual, group, and organizational (Di Milia \& Birdi, 2010). The AO is not an automatic process. As such, four organizational conditions are necessary: Culture of organizational learning, training, strategic clarity, and organizational support (Castañeda, 2010).

The culture of organizational learning as the first condition is the connection between the exchange of knowledge and practical solution to the problems of an entity. Training as a second condition is a vital process which is socioculturally intentional (Mendoza, 2015). The third condition for the OL is strategic clarity. This condition involves the knowledge workers on the mission, vision, objectives, and strategy of the organization. The fourth condition for the OL in an institution is organizational support. This condition allows the availability of physical and technological resources to share knowledge. They include computers, information technology and communication, software, and infrastructure. However, the support of leaders that is part of the culture of organizational learning is not included. The technological infrastructure is a predictor of success in initiatives based on the knowledge of the organization (Yang \& Chen, 2007).

The model of organizational learning 4I establishes some principles: organizational learning is on several levels (individual, group, and organizational). Social and psychological processes linking the three levels of OL and cognition affects the action and vice versa. However, there are few investigations (Crossan, Maurer \& White, 2011). 
4I model of Crossan et al. (1999) identifies four learning processes: Intuition, Interpretation, Integration, and Institutionalization (Figure 1). Intuition is a personal level. It is a preconscious or pattern recognition of the inherent possibilities of experience. The interpretation occurs in the individual and group levels. This process explains, in words or actions, an idea of oneself and others. Integration is the process of mutual understanding between people and coordinated action through mutual adaptation. Institutionalization is the process of ensuring that routine actions occur. This learning process produced by individuals and groups in the organization includes the systems, structures, procedures, and strategies (Duarte \& Castañeda, 2013).

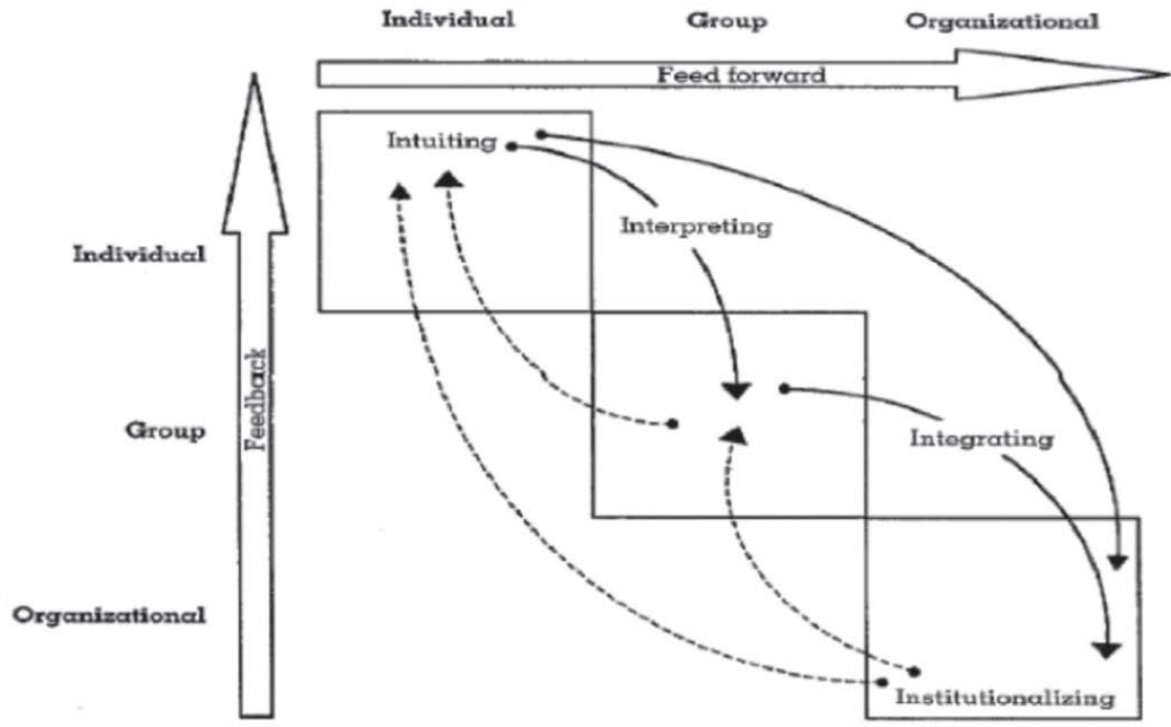

Figure 1. 4I Model of Organizational Learning Source: Crossan, Lane \& White (1999, p. 532).

Studies and competition strategy of the company allow increasing the competitiveness and organizational learning. These studies increase the ability to stay in the market without sacrificing the benefits. Also, the OL as a strategic factor in the organization has led to new hierarchical structures of knowledge management. However, technological developments in computing and electronics make knowledge obsolete in no time. Given these scenarios, managers cannot afford to ignore the OL competitive and strategic advantages. It is not a management fad, but a factor of real competitiveness. Probably, the AO acquires the quality of strategic competitive advantage for the category of knowledge as an essential element in the organization (Moguel, 2005).

The SECI model Nonaka, and Takeuchi establish two dimensions: an epistemological dimension that distinguishes the explicit and tacit 
knowledge. The first allows express them easily captured, stored and reused. Moreover, Tacit knowledge is personal. This knowledge is difficult to formalize and communicate to others. An ontological dimension also distinguishes between four levels of agent's creators of knowledge: individual, group, organization, and inter-organizational level. (Navarro, Villasalero \& Donate, 2015).

Knowledge (Figure 2) is the representation or symbolic expression of conscious aspects and assets of a universe of discourse nominee. Consequently, knowledge is tacit or implicit and explicit in his evidence (Lahaba, 2015).

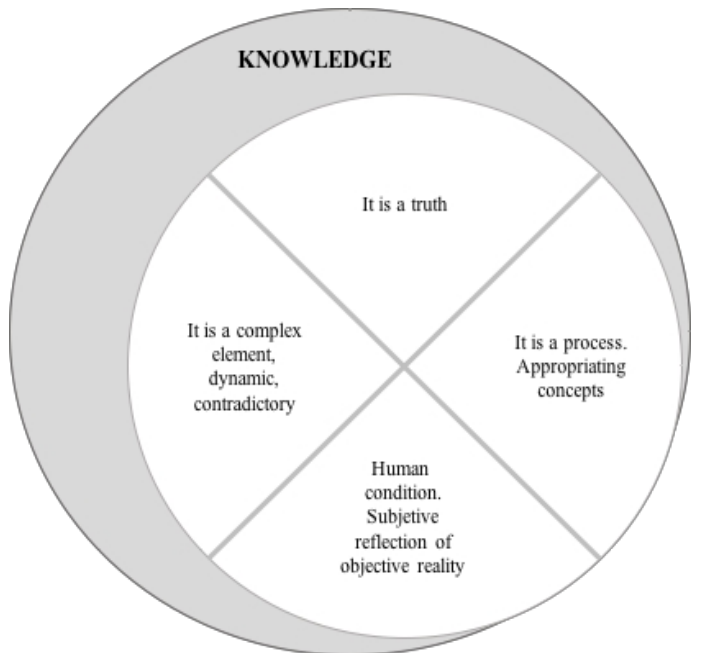

Figure 2. Approach to knowledge Source: Lahaba (2015, p. 32)

Knowledge as a strategic asset for organizations is an asset of organizational knowledge. The business context identifies the existence of strategic knowledge and orients improving the critical processes of the organization aligned to the strategic objectives of the company (Lampen, 2011).

Once established, the relationship between knowledge and the strategic aspects of the organization is possible in enhancing their knowledge. This process marks the beginning of assets known as OL. These assets are qualitatively superior strategic knowledge that the organization can learn. Table 1 shows the notable performance and special conditions between knowledge assets and OL assets (Lahaba, 2015). 
Table 1. Differences between knowledge assets and assets of organizational learning.

Source: Lahaba (2015, p. 35)

Knowledge Assets

Assets affects OL.

The organization learns from them casually.

They are related to the field of activity of the organization.

Influence all organizational processes.

They are scattered throughout the organization.

When combined, they originate valuable aspects for the organization.

They are bad and good practices.

They do not achieve positive differentiation of the organization in its environment.

They are general and specific.

They are useful locally.

They have multiple classifications.
Assets OL

Power connections between the assets of OL and knowledge assets.

The organization learns from them when scheduled.

They are directly linked to organizational goals.

Impacts on key organizational processes. They focus on individuals or groups of people. They are valuable expertise to the organization.

They are good practice.

Positively identify the organization in its environment

They are complex, specific and highly specialized.

They are socially useful.

They are classified according to the organizational context.

The approach of the US government with the Cuban government offers three economic reforms to support its citizens: promoting the small business sector in Cuba, promote US investment, and tourism to the island. The relatively small and impoverished market is 11 million, and workers have an average monthly income of \$20. However, Cuba currently has some 436.000 persons licensed to perform activities on their own. Most of them are involved in food preparation or sales in private restaurants known as "Paladars" (Azel, 2015).

Furthermore, there is no consensus on the family business concept in the scientific community. The truth is that most authors identify the following main dimensions: The family involvement in ownership and/or administration of the company and the mutual dependence between variables ownership and management (Henry, 2012).

The family system attempts to limit change and balance within it. On the other hand, the company system focuses on performing tasks and oriented outward. Although both systems have different objectives, the interaction can provide benefits and offer the family company a unique competitive advantage over non-family firms (Barroso, 2013).

One of the keys to the survival of the family business is the transfer of knowledge among family members and the changes that new generations must take to adapt. Knowledge transfer within the same company through generations explains why most family businesses do not survive the third generation. However, these organizations have a much higher rate of mortality during the transition of ownership to the second generation. The 
departure of a key precursor of the family could lead to a significant lack of expertise to the success of the family business. Also, the transfer of knowledge is of great importance (Durst \& Wilhelm, 2012).

\section{Methodology}

The research design is not experimental and correlational crosssectional. The SOL model proposes four levels and three categories. The levels are Support Organizational, Training, Clarity Strategic, and Organizational Culture. The categories are Ontological Knowledge, Organizational Conditions, and Epistemic Knowledge (Figure 3). Thus, this model fits into the conditions necessary to create a competitive advantage in small and medium-sized family businesses paladars calls belonging to SME sector Horeca in Havana, Cuba.

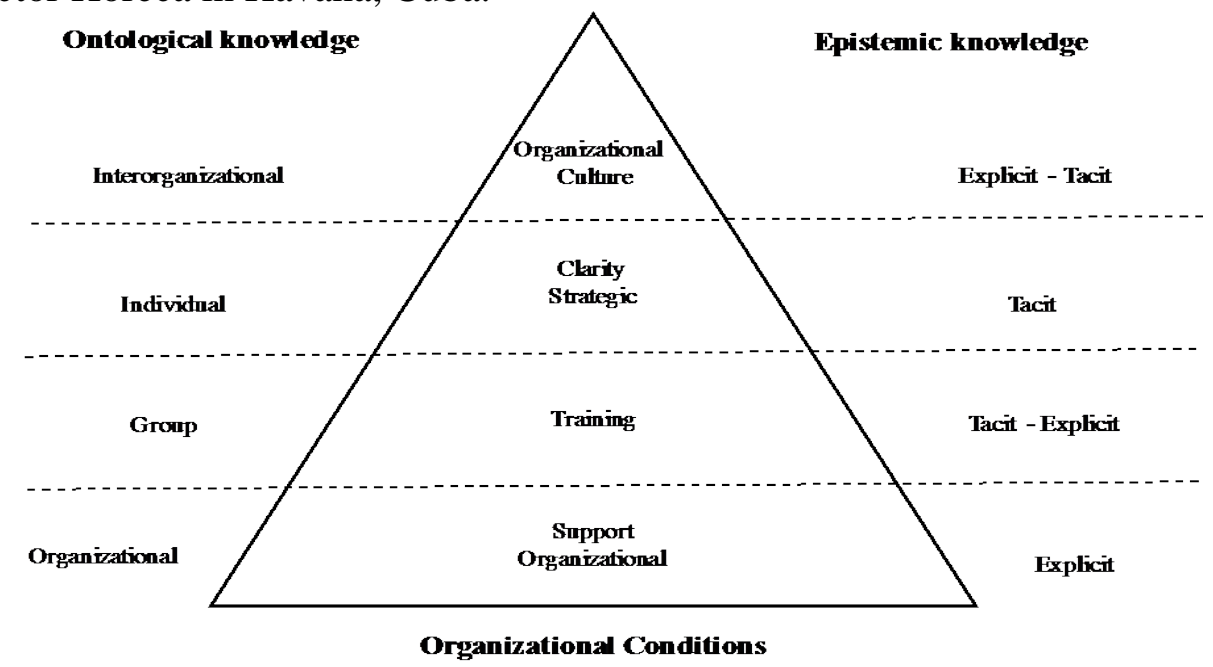

Figure 3. Organizational Learning Strategic Model

Knowledge transfer (KT) within the same company through generations explains why most family businesses do not survive in the third generation (Durst \& Wilhelm, 2012). Thus, the strategic organizational learning model obtained by equation (1) measures the amount of knowledge transfer achieved.

$$
K T=\frac{\sum_{i=1}^{n} O k n+\sum_{j=1}^{n} O c o+\sum_{k=1}^{n} E k n}{t}
$$

Where:

$K T=$ Knowledge Transfer.

Okn = Ontological Knowledge.

Oco $=$ Organizational Conditions.

$E k n=$ Epistemic Knowledge.

$t=$ Time (Weekly $=7$, Fortnightly $=15$, Monthly $=30$ ) 
Table 2 presents the values assigned to the indicators in each of the categories and levels of the model for the maximum score achieved.

\begin{tabular}{|c|c|c|c|c|c|}
\hline \multirow{2}{*}{ Category } & \multirow{2}{*}{ Level } & \multirow{2}{*}{ Indicator } & \multicolumn{3}{|c|}{ Time } \\
\hline & & & Weekly & Fortnightly & Monthly \\
\hline \multirow{4}{*}{ Okn } & Organizational & Performance & 6 & 50 & 100 \\
\hline & Group & Attitudes & 6 & 50 & 100 \\
\hline & Individual & Values & 6 & 50 & 100 \\
\hline & $\begin{array}{c}\text { Inter- } \\
\text { organizational }\end{array}$ & Interoperability & 5 & 50 & 100 \\
\hline \multirow{4}{*}{ Oco } & $\begin{array}{l}\text { Organizational } \\
\text { Support }\end{array}$ & Usability & 6 & 50 & 100 \\
\hline & Training & Availability & 6 & 50 & 100 \\
\hline & $\begin{array}{c}\text { Strategic } \\
\text { Clarity }\end{array}$ & Modifiability & 6 & 50 & 100 \\
\hline & $\begin{array}{l}\text { Organizational } \\
\text { Culture }\end{array}$ & Security & 6 & 50 & 100 \\
\hline \multirow{5}{*}{ Ekn } & Explicit & Procedures & 6 & 50 & 100 \\
\hline & Tacit-Explicit & $\begin{array}{l}\text { Experience- } \\
\text { Procedures }\end{array}$ & 6 & 50 & 100 \\
\hline & Tacit & Abilities & 6 & 50 & 100 \\
\hline & Explicit-Tacit & $\begin{array}{l}\text { Procedures- } \\
\text { Abilities }\end{array}$ & 5 & 50 & 100 \\
\hline & Totals & & 70 & 150 & 300 \\
\hline
\end{tabular}

The empirical study is weekly, and hypothesis testing is as follows:

$\mathrm{H}_{0}: K T>12$ average alleged in a week.

$\mathrm{H}_{1}: K T \leq 12$ average alleged in a week.

With the information gathered of the probability sample size for the study was calculated.

$\mathrm{N}=$ Population size (number of paladars in Havana Cuba) $=63$

$\mathrm{p}=$ Probability of occurrence of the phenomenon $=0,9$

se $=$ Standard error $=0,05$

$\mathrm{S}^{2}=$ Variance of the sample expressed as a probability of occurrence. $\mathrm{S}^{2}=$ $\mathrm{p}(1-\mathrm{p})$

$\mathrm{V}^{2}=$ Variance of the population squared $\left(\mathrm{se}^{2}\right)$.

Substituting the values in equations (2) and (3):

$$
n^{\prime}=\frac{S^{2}}{V^{2}}
$$

$$
n=\frac{n^{\prime}}{1+n^{\prime} / N}
$$

The sample size is 23 paladars. Thus, a total of 822 observations corresponds to Okn 260, Oco 287, and Ekn 275. The variance is equal to 885,0483 while the standard deviation is 3,7481 .

Hypothesis testing provides:

$$
\begin{array}{ll}
\mu_{\mathrm{H} 0}=12 & \overline{\mathrm{x}}_{\text {Okn }}=11,30 \\
\sigma=3,7481 & \overline{\mathrm{x}}_{\text {Oco }}=12,47 \\
& \overline{\mathrm{x}}_{\text {Ekn }}=11,96
\end{array}
$$


Equation (4) calculates the standard error of the mean:

(4)

$$
\sigma_{i=\frac{\sigma}{\sqrt{n}}}
$$

The results indicate that the standard error of the mean is equal to 0,7815. Besides, 0,95 of the acceptance region contains two equal areas and 0,475 Level of significance 0,5 . In the normal distribution, the table corresponds to 1,96 . This information allows the calculation of the upper and lower limits based on the equation (5) and (5a).

$$
\begin{aligned}
& \mu_{H 0+1.96 \sigma_{i}} \\
& \mu_{H 1-1.96 \sigma_{i}}
\end{aligned}
$$

The upper limit is equal to 13,5317 while the lower limit is equal to 10,4683 (Figure 4).

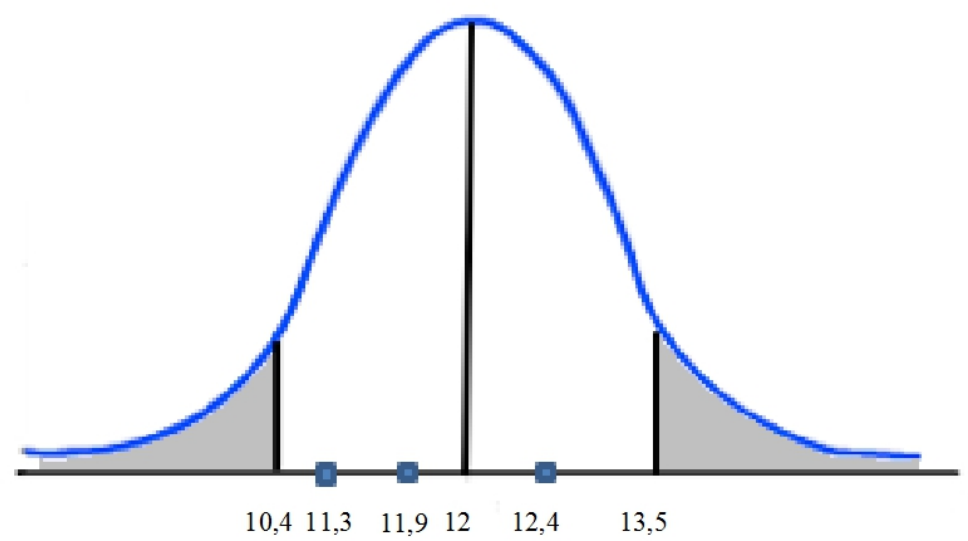

Figure 4. Hypothesis testing two extremes.

The values assigned to each category of indicators according to time are optimal. KT in equation (1) is an inversely proportional relationship between the three categories with respect to time that make up the SOL Model. The metric interprets the results and sets the level of learning.

Table 3. Metrics to measure the strategic organizational learning

Strategic Organizational Learning

High / Very High

Satisfactory

Medium / Regular

Low / Bad

Non-Existent
Knowledge Transfer - Score

$$
\begin{array}{ccc}
\text { Weekly } & \text { Fortnightly } & \text { Monthly } \\
8-10 & 16-20 & 32-40 \\
6-7,9 & 12-15,9 & 24-31,9 \\
4-5,9 & 8-11,9 & 16-23,9 \\
2-3,9 & 4-7,9 & 8-15,9 \\
0-1,9 & 0-3,9 & 0-7,9
\end{array}
$$

A questionnaire was applied to the owner of each of the 23 paladars to measure knowledge transfer and to determine the level of SOL in the organization (Table 4). 
Table 4. The level of SOL in the organization.

\begin{tabular}{|c|c|c|c|c|c|}
\hline Sample & $\begin{array}{l}\text { Ontological } \\
\text { Knowledge }\end{array}$ & $\begin{array}{l}\text { Organizational } \\
\text { Conditions }\end{array}$ & $\begin{array}{l}\text { Epistemic } \\
\text { Knowledge }\end{array}$ & $\begin{array}{l}\text { Knowledge } \\
\text { Transfer }\end{array}$ & $\begin{array}{c}\text { Strategic } \\
\text { Organizational } \\
\text { Learning }\end{array}$ \\
\hline 1 & 14 & 15 & 5 & $34 / 7$ & $\begin{array}{c}\text { Medium / } \\
\text { Regular }\end{array}$ \\
\hline 2 & 10 & 10 & 15 & $35 / 7$ & $\begin{array}{l}\text { Medium / } \\
\text { Regular }\end{array}$ \\
\hline 3 & 15 & 12 & 19 & $46 / 7$ & Satisfactory \\
\hline 4 & 11 & 18 & 7 & $36 / 7$ & $\begin{array}{l}\text { Medium / } \\
\text { Regular }\end{array}$ \\
\hline 5 & 12 & 10 & 11 & $33 / 7$ & $\begin{array}{l}\text { Medium / } \\
\text { Regular }\end{array}$ \\
\hline 6 & 14 & 8 & 8 & $30 / 7$ & $\begin{array}{l}\text { Medium / } \\
\text { Regular }\end{array}$ \\
\hline 7 & 8 & 12 & 12 & $32 / 7$ & $\begin{array}{l}\text { Medium / } \\
\text { Regular }\end{array}$ \\
\hline 8 & 11 & 15 & 17 & $43 / 7$ & Satisfactory \\
\hline Sample & $\begin{array}{l}\text { Ontological } \\
\text { Knowledge }\end{array}$ & $\begin{array}{c}\text { Organizational } \\
\text { Conditions }\end{array}$ & $\begin{array}{l}\text { Epistemic } \\
\text { Knowledge }\end{array}$ & $\begin{array}{l}\text { Knowledge } \\
\text { Transfer }\end{array}$ & $\begin{array}{l}\text { Strategic } \\
\text { Organizational } \\
\text { Learning }\end{array}$ \\
\hline 9 & 17 & 17 & 7 & $41 / 7$ & $\begin{array}{c}\text { Medium / } \\
\text { Regular }\end{array}$ \\
\hline 10 & 10 & 11 & 12 & $33 / 7$ & $\begin{array}{l}\text { Medium / } \\
\text { Regular }\end{array}$ \\
\hline 11 & 15 & 12 & 15 & $42 / 7$ & Satisfactory \\
\hline 12 & 12 & 9 & 9 & $30 / 7$ & $\begin{array}{l}\text { Medium / } \\
\text { Regular }\end{array}$ \\
\hline 13 & 17 & 16 & 17 & $50 / 7$ & Satisfactory \\
\hline 14 & 15 & 17 & 14 & $46 / 7$ & Satisfactory \\
\hline 15 & 9 & 15 & 12 & $36 / 7$ & $\begin{array}{l}\text { Medium / } \\
\text { Regular }\end{array}$ \\
\hline 16 & 12 & 13 & 10 & $35 / 7$ & $\begin{array}{l}\text { Medium / } \\
\text { Regular }\end{array}$ \\
\hline 17 & 15 & 9 & 11 & $35 / 7$ & $\begin{array}{l}\text { Medium / } \\
\text { Regular }\end{array}$ \\
\hline 18 & 7 & 10 & 19 & $36 / 7$ & $\begin{array}{l}\text { Medium / } \\
\text { Regular }\end{array}$ \\
\hline 19 & 12 & 12 & 8 & $32 / 7$ & $\begin{array}{l}\text { Medium / } \\
\text { Regular }\end{array}$ \\
\hline 20 & 8 & 15 & 12 & $35 / 7$ & $\begin{array}{l}\text { Medium / } \\
\text { Regular }\end{array}$ \\
\hline 21 & 4 & 9 & 11 & $24 / 7$ & Low / Bad \\
\hline 22 & 7 & 10 & 14 & $31 / 7$ & $\begin{array}{l}\text { Medium / } \\
\text { Regular }\end{array}$ \\
\hline 23 & 5 & 12 & 10 & $27 / 7$ & Low / Bad \\
\hline
\end{tabular}

Note: Scores Maximum for Ontological Knowledge: 23. Organizational Conditions: 24.

Epistemic Knowledge: 23. Knowledge Transfer is divided between 7 because the empirical study is weekly. 
The information above shows that only level SOL has every Paladar. However, it is desirable to determine the relationship between learning and competence between Paladars. In doing so, the following assumptions were set out:

$\mathrm{H}_{\mathrm{i}}$ : SOL and Knowledge Transfer high are independent competition among Cuban Paladar.

$\mathrm{H}_{0}$ : SOL and Knowledge Transfer low are dependent on the competition between the Cuban Paladar.

Chi-square test of independence is used to validate the research hypothesis by the following contingency table (Table 5).

Table 5. Table of Contingencies

$\begin{array}{ccccc} & \begin{array}{c}\text { Ontological } \\ \text { Knowledge }\end{array} & \begin{array}{c}\text { Organizational } \\ \text { Conditions } \\ 138\end{array} & \begin{array}{c}\text { Epistemic } \\ \text { Knowledge }\end{array} & \text { Total } \\ \begin{array}{c}\mathrm{H}_{\mathrm{i}}: \text { KT High } \\ \text { in SOL }\end{array} & 138 & 145 & 429 \\ \begin{array}{c}\mathrm{H}_{0}: \text { KT Low } \\ \text { in SOL }\end{array} & 122 & 141 & 130 & 393 \\ \quad \text { Total } & 260 & 287 & 275 & 822\end{array}$

Equation (6) indicates the Combined Proportion of $K T$ high in SOL.

$$
C P=\frac{O k n+O c o+E k n}{T O k n+T O c o+T E k n}
$$

Combined Proportion is equal to 0,4781 , and its supplement is equal to 0,5219 .

Table 6 shows the estimation of the Combined Proportion.

Table 6. Estimates of the Combined Proportion

Ontological

Knowledge

$\mathrm{H}_{\mathrm{i}}$ : KT High in

SOL

$\mathrm{H}_{0}: K T$ Low in

SOL
Organizational Conditions $287 \times 0,4781$

\begin{tabular}{ll}
$=124,306$ & $=137,2147$ \\
\hline $260 \times 0,5219$ & $287 \times 0,5219$ \\
$=135,694$ & $=149,7853$
\end{tabular}

$=149,7853$
Epistemic

Knowledge $275 \times 0,4781$ $=131,4775$ $275 \times 0,5219$ $=143,5225$

Table 7 shows the comparison of the observed and expected frequencies. 
Table 7. Comparison of observed and expected frequencies

Actual Observed

Frequency. KT High in

SOL

Expected Frequency

(Theoretical)

Actual Observed

Frequency. KT Low in

SOL

Expected Frequency

(Theoretical)
Ontological

Knowledge

122

124,306

Ontological

Knowledge

138

135,694
Organizational

Conditions

141

137,2147

Organizational

Conditions

146

149,7853
Epistemic

Knowledge

130

131,4775

Epistemic

Knowledge

145

143,5225

According to the equation 7 and substituting the values in Table 8, the Chi-square value is equal to 0,3138 .

$$
\chi^{2}=\sum \frac{(f o-f e)^{2}}{f e}
$$

Table 8. Calculation of Chi-square

\begin{tabular}{ccccc}
$\boldsymbol{f o}$ & $\boldsymbol{f e}$ & $\boldsymbol{f o}-\boldsymbol{f e}$ & $\begin{array}{l}(\boldsymbol{f o} \\
-\boldsymbol{f e})^{\mathbf{2}}\end{array}$ & $\frac{(\boldsymbol{f o}-\boldsymbol{f e})^{\mathbf{2}}}{\boldsymbol{f e}}$ \\
141 & 137,2147 & 3,7853 & 14,3284 & 0,1044 \\
122 & 124,306 & $-2,3060$ & 5,3176 & 0,0427 \\
130 & 131,4775 & $-1,4775$ & 2,1830 & 0,0166 \\
146 & 149,7853 & $-3,7853$ & 14,3284 & 0,0957 \\
138 & 135,694 & 2,3060 & 5,3176 & 0,0392 \\
145 & 143,5225 & 1,4775 & 2,1830 & 0,0152 \\
\hline & & & $\chi^{2}$ \\
& & &
\end{tabular}

Equation (8) is used to calculate the number of degrees of freedom.

(8) Number of degrees of freedom $=(r-1)(c-1)$

The number of degrees of freedom is equal to 2 . The statistical means with 2 degrees of freedom of the region to the right of Chi-square of 3,2190 contains 0,20 of the area under the curve (Figure 5). 


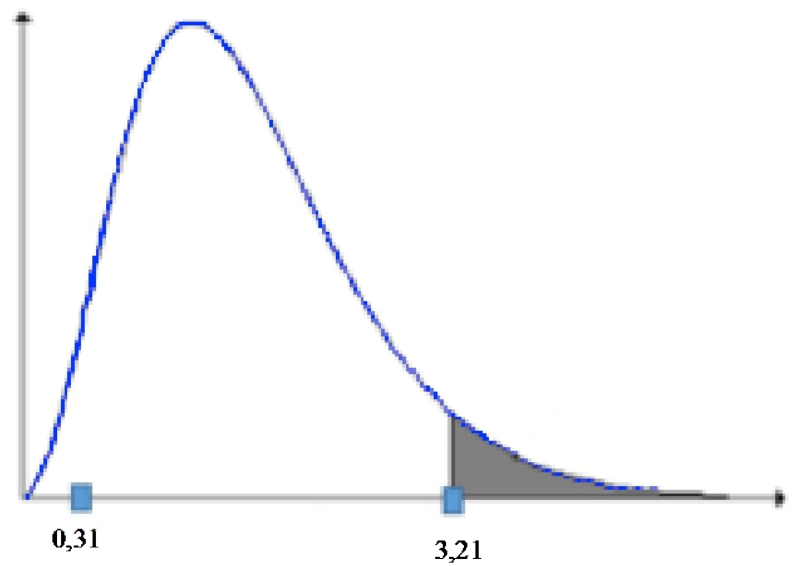

Figure 5. Hypothesis testing Chi-square at the significance level 0,20

\section{Results}

Equation (1) states that the greater the transfer of knowledge, the greater will be the Strategic Organizational Learning within the organization. The Figure 4 shows that the mean Okn, Oco, and Ekn are within the zone of acceptance. Therefore, hypothesis testing is approved. Also, Table 4 shows the values achieved in the different categories. This information indicates that the transfer of knowledge and fashion notes that the SOL paladars are Medium/Regular as a representative sample in Havana, Cuba. In Figure 5, the value of Chi-square 0,3138 falls within the acceptance region. Therefore, the research hypothesis is true and shows that the SOL in every paladar is independent of its competence.

\section{Conclusion}

There are many myths regarding the standard of living and the behavior of family SMEs in Havana, Cuba. There is no HORECA sector formally constituted. A Paladar is very expensive for the Cuban consumer because wages is very low. The average monthly salary is 23 dollars, and the costs of the dishes cost $\$ 5$ to $\$ 7$. Therefore, this is a saucer equivalent to $30 \%$ of their monthly salary.

The remittances are the primary source of funding for local consumer public. Also, there is no concept of credit or benefits such as bonuses. However, health services and education are free.

The general consumer is mostly foreign tourists. There is an unwritten agreement between taxis and paladars. Taxi drivers receive a commission in money or in kind (food and beverages) in bringing visitors to these establishments. The 23 interviewed paladars require greater organizational support to enhance their strategic organizational learning. The Internet service is inaccessible, and the provision of internet facilities is very 
expensive and restricted. The training to improve their activities is low. However, the Paladar Asturiano receives support from the Spanish community and La Floridita from the Cuban-American community in Miami, Florida. Also, there is no adequate strategic clarity because most palates are not aware of the organizational mission and vision.

There are strong ties between the Cuban community, the European Economic Community, Canada, China, some countries in Africa and Latin America. These relationships promote organizational culture but in a disjointed for the HORECA sector.

The Ontological knowledge and epistemic knowledge observed in staff and the owners of such establishments is empirical. SOL is Medium/Regular in most establishments. However, competition between these establishments is independent of this type of learning. As a result, each of them can achieve differentiation for competitive advantage. However, prepared food chains the US in Havana, Cuba will be a strong competitor for the paladars at risk of perishing. However, increasing the SOL will give them a competitive advantage in the sector.

\section{References:}

Alavi, M., \& Denford, J. S. (2011). Knowledge management: Process, practice, and web 2.0. Handbook of Organizational Learning and Knowledge Management, 105-124.

Antonello, C. S., \& Godoy, A. S. (2011). Aprendizagem organizacional e as raízes de sua polissemia. Aprendizagem organizacional no Brasil, 31-50.

Aponte, S. P. D., \& Zapata, D. I. C. (2013). A model of organizational learning in practice. Estudios Gerenciales, 29(129), 439-444.

Azel, J. (2015). The new Cuba policy. World Affairs, 178(3), 19-28.

Castañeda, D. I. (2010). Variables psicosociales y condiciones organizacionales intervinientes en la intención y conducta de compartir conocimiento [disertación doctoral]. Madrid, España: Facultad de Psicología, Universidad Autónoma de Madrid.

Crossan, M. M., Lane, H. W., \& White, R. E. (1999). An organizational learning framework: From intuition to institution. Academy of management review, 24(3), 522-537.

Crossan, M. M., Maurer, C. C., \& White, R. E. (2011). Reflections on the 2009 AMR decade award: do we have a theory of organizational learning? Academy of Management Review, 36(3), 446-460.

Dávalos, L. L. (2015). Cuba: Hacia cinco años de reformas. Actualidad Juridica (1578-956X), (39), 147-152.

Di Milia, L., \& Birdi, K. (2010). The relationship between multiple levels of learning practices and objective and subjective organizational financial performance. Journal of Organizational Behavior, 31(4), 481-498. 
Durst, S., \& Wilhelm, S. (2012). Knowledge management and succession planning in SMEs. Journal of Knowledge Management, 16(4), 637-649.

Embajada de España en Kuwait. Oficina Económica y Comercial,. (2013). El mercado del canal Horeca en Kuwait 2013. (5). Kuwait: ICEX.

Henry, M. (2012). Tacit Knowledge Transfer in Family Business Succession. Doctoral Thesis. University of Southern Queensland. Canada.

Hoyos, D. F. (2014). Imagen de Cuba como destino país percibida por el Turismo de Eventos/Cuba's perceived Image by Events Tourism. Retos Turísticos, 13(2).

Lahaba, Y. R. N. (2015). Activos de aprendizaje organizacional un activo de conocimiento crítico. Ciencias de la Información, 46(3), 31-37

Lampen, M. A. C. (2011). Modelo de gestión del conocimiento estratégico para la Facultad de Ingeniería y Arquitectura de la Universidad de San Martín de porres. Strategic knowledge management model for. Cultura / Universidad de San Martín de Porres (25), 307-322.

Martínez, A. B. (2013). La importancia de la gestión del conocimiento en el espíritu emprendedor de las empresas familiares (Doctoral dissertation, Universidad de Extremadura).

Mendoza, B. I. L. (2015). La formación permanente en condiciones y contexto de universalización de la educación superior en Cuba. Pedagogía Universitaria, 20(3), 78-92.

Moguel, M. (2005). Aprendizaje Organizacional: Naturaleza, Evolución y Perspectivas. Estudio de Caso en Cuatro Organizaciones en México. Universidad Autónoma de Chiapas. Colección ciencia y tecnología. México, 143-145.

Navarro, K., Villasalero, M., \& Donate, M. (2015). Especificidad de la Composición del Conocimiento en las Empresas Familiares. Revista Venezolana de Gerencia, 19(66). 339-360.

Stable-Rodríguez, Y. (2016). Aprendizaje organizacional en organizaciones de ciencia tecnología e innovación. Ingeniería Industrial, 37(1), 78-90.

Yang, C., \& Chen, L. C. (2007). Can organizational knowledge capabilities affect knowledge sharing behavior? Journal of Information Science, 33(1), 95-109. 